\title{
PREVALENCE OF URINARY TRACT INFECTION IN PREGNANT WOMEN IN KATIHAR DISTRICT, BIHAR
}

\author{
Tarannum Yasmin 1 , M. Yousuf Sarwar², Aninda Sen ${ }^{3}$
}

1 Professor, Department of Microbiology, Katihar Medical College, Katihar.

2 Associate Professor, Department of Anatomy, Katihar Medical College, Katihar.

3 Professor, Department of Microbiology, Katihar Medical College, Katihar.

\section{BACKGROUND}

ABSTRACT

Urinary tract infections (UTI) are the common bacterial infections during pregnancy. It may involve the lower urinary tract or bladder. The majority of UTI occur due to ascending infection. Untreated UTI can be associated with serious obstetric complications.

The aim of this study was to examine the prevalence of UTI, proper screening and treatment of pregnant woman is necessary to prevent complications.

\section{MATERIALS AND METHODS}

This study included 350 cases of pregnant women over a period of 1 year. UTI was diagnosed using mid-stream (MSU) culture using $>10^{5}$ colony forming unit per millilitre as a significant level of bacteriuria.

\section{RESULTS}

A total of 350 samples were processed during the study period, of which 98 cases showed significant growth making prevalence of $28 \%$. There was a high incidence in $21-25$ years' age group (48.97\%). There was also high incidence of infection in the third trimester of pregnancy (73.46\%) compared to first (7.14\%) and second trimester (19.38\%). Multiparity is associated with increased urinary tract infection in pregnancy.

\section{CONCLUSION}

The present study shows the prevalence rate of $28 \%$ of UTI among pregnant women. These findings underscore the importance of screening of all pregnant women for significant bacteriuria, so that positive cases should be treated subsequently with antibiotics in order to reduce the adverse effects on both maternal and foetal health.

\section{KEYWORDS}

Prevalence, Pregnant Women, UTI, Bacteriuria.

HOW TO CITE THIS ARTICLE: Yasmin T, Sarwar MY, Sen A. Prevalence of urinary tract infection in pregnant women in Katihar district, Bihar. J. Evolution Med. Dent. Sci. 2018;7(03):372-375, DOI: 10.14260/jemds/2018/82

\section{BACKGROUND}

Urinary tract infections (UTI), which are caused by the presence and growth of microorganisms in the urinary tract are perhaps the single commonest bacterial infections of mankind,(1) and in pregnancy it may involve the lower urinary tract of the bladder.(2) UTI has been reported among $20 \%$ of the pregnant women and it is the most common cause of admission in obstetrical wards. (3)

Anatomically, UTI can be classified into lower urinary tract infection involving the bladder and urethra and upper urinary tract infection involving the kidney, pelvis and ureter. The majority of the UTI occur due to ascending infection. $(4,5)$ Pregnancy causes numerous changes in the woman's body. Hormonal and mechanical changes increase the risk of urinary stasis and vesicoureteral reflux. These changes along with an already short urethra (approximately $3-4 \mathrm{~cm}$ in females) and difficulty with hygiene due to a distended

'Financial or Other Competing Interest': None.

Submission 06-12-2017, Peer Review 30-12-2017,

Acceptance 05-01-2018, Published 13-01-2018.

Corresponding Author:

Dr. M. Yousuf Sarwar,

Department of Anatomy

Katihar Medical College

Katihar-854105,

Bihar.

E-mail: drmysarwar@gmail.com

DOI: $10.14260 /$ jemds $/ 2018 / 82$ pregnant belly increase the frequency of urinary tract infections in pregnant women.

After anaemia UTIs are the second common complications in pregnant women, which is not controlled well, can adversely affect the health of an infant or the pregnant mother.(6,7) Pregnancy UTI is classified into two categories of symptomatic and asymptomatic.(8,9) Asymptomatic- The involvement of the lower urinary tract leading to asymptomatic bacteriuria is the most common cause of UTI during pregnancy. Symptomatic- The involvement of the upper urinary tract can lead to symptomatic bacteriuria and is characterised by acute pyelonephritis.(10)

UTI is defined as the presence of at least 100,000 organisms per millilitre of urine in an asymptomatic patient or as more than 100 organisms/ $\mathrm{mL}$ of urine with accompanying pyuria ( $>5 \mathrm{WBCs} / \mathrm{mL}$ ) in a symptomatic patient. Particularly, in asymptomatic patients, a diagnosis of UTI should be supported by a positive culture for an uropathogen.(11) Untreated asymptomatic bacteriuria is a risk factor for acute cystitis (40\%) and pyelonephritis (25\%-30\%) in pregnancy. These cases account for $70 \%$ of all cases of symptomatic UTI among unscreened pregnant women.(11) Symptomatic and asymptomatic bacteriuria have been reported among $17.9 \%$ and $13.0 \%$ pregnant women, respectively.(12)

In recent years bacteriuria of pregnancy has drawn attention of obstetricians all over the world, because of its effects on mother and foetus. Pregnant women are at 
increased risk for UTIs. Beginning in 6 weeks which peaks during 22 - 26 weeks,(13) and continues to persist until delivery. This is also known as "hydronephrosis of pregnancy." Both progesterone and oestrogen levels increase during pregnancy and these will lead to decreased ureteral and bladder tone. Increased plasma volume during pregnancy leads to decreased urine concentration and increased bladder volume. The combination of all these factors lead to urinary stasis and ureterovesicle reflux.(4) Additionally, the apparent reduction in immunity of pregnant women appears to encourage the growth of both commensal and noncommensal microorganisms. ${ }^{(14)}$

Increased age, number of childbirths, number of intercourses per week, diabetes, recessive sickle cell anaemia, previous history of UTI, immunodeficiency and urinary tract abnormalities can increase the risk of UTI in pregnant women.(15,16) Bacterial organisms which cause this disease include Escherichia coli, Klebsiella pneumonia, Proteus, Acinetobacter, Staphylococcus saprophyticus, Group B streptococci and Pseudomonas aeruginosa.(10,15,16,17)

The purpose of this study was to examine the prevalence of UTI, proper screening and treatment of pregnant women is necessary to prevent complications.

\section{MATERIALS AND METHODS}

The study was conducted over a period of 1 year from June 2016 to May 2017 in the Department of Microbiology, Katihar Medical College and Hospital, Katihar, Bihar, India. Antenatal women who presented at the antenatal clinic during the study period were randomly recruited into the study upon verbal informed consent; either had any of the symptoms suggestive of urinary tract infections or without any symptoms was included. Pregnant women having renal disease or an antibiotic therapy within 72 hours to the study days were excluded due to the fact that the antibiotic must have inhibited or destroyed the pathogens. 350 pregnant women with or without symptoms of UTI were included in this study. Verbal informed consent was obtained from each woman before the commencement of the research. Sociodemographic data such as age, occupation, parity and duration of gestation were collected from the pregnant women using standard questionnaires and kept confidential during the research.

Early morning clean-catch midstream urine was collected from each pregnant woman into a wide-mouthed sterile screw-capped container. With a Calibrated micro-loop 0.001 $\mathrm{mL}$ of urine was cultured on to a Blood agar and a MacConkey agar plate. After overnight incubation at $370 \mathrm{C}$ for 24 hours, colony counts yielding bacterial growth of $\geq 105 / \mathrm{mL}$ was taken as being significant in both symptomatic and asymptomatic pregnant women. Centrifuged urine deposit was examined microscopically at high magnification for pus cells, red blood cells, epithelial cells, casts, crystals and yeastlike cells. After the bacteria are isolated, colony counting will be done in colony counter. If significant number of bacteria is found it will be biochemically confirmed. The isolate if found positive, pathogen will be processed for antibiotic susceptibility testing by Kirby and Bauer's method with the commonly used antibiotics and chemotherapeutic agents.

Antibiotics used are amoxicillin, amoxyclav, amikacin, gentamicin, imipenem, ceftriaxone, cefuroxime, nitrofurantoin, ceftazidime, piperacillin + tazobactam, cefazolin and clindamycin.

\section{RESULTS}

Three hundred and fifty (350) urine samples were collected and analysed during the study period, in which 252 samples showed no growth and 98 samples showed significant growth making prevalence of 98/350 (28\%) [Table 1].

The prevalence of infection in relation to age are shown in [Table 2], individuals of age group 21 - 25 years had the highest incidence of infection 48/98 (48.97\%) followed by age group 26 - 30 years 36/98 (36.73\%), 31 - 35 years 09/98 $(9.18 \%)$ and $16-20$ years $03 / 98(3.06 \%)$. While the age group 36 - 40 years had the lowest incidence of infection 02/98 (2.06\%).

The prevalence of infection in relation to gestational age is shown in [Table 3]. Higher rate of infection in third trimester [26 - 40 weeks] of 72/98 (73.46\%) compared to second trimester [13 - 25 weeks] of $19 / 98$ (19.38\%) and first trimester [1 - 12 weeks] of 7/98 (7.14\%).

The prevalence of infection in relation to gravida is shown in [Table 4]. Highest incidence is seen in multigravida 57/98 $(58.16 \%)$ and lowest incidence is seen in primigravida $9 / 98$ (9.18\%).

The gold standard for detecting bacteriuria in pregnancy is urine culture. Table 5 showed the frequency of various isolated pathogens. 252 samples had no growth, 98 samples were positive for urinary pathogens. Among the significant isolates E. coli had the highest percentage of isolation 56/98 $(57.14 \%)$, while the lowest was proteus species of $4 / 98$ (4.08\%).

\begin{tabular}{|c|c|c|}
\hline Prevalence & Cases & Percentage \\
\hline UTI & 98 & $28 \%$ \\
\hline Non-UTI & 252 & $72 \%$ \\
\hline Total & $\mathbf{3 5 0}$ & $\mathbf{1 0 0} \%$ \\
\hline Table 1. Prevalence Rate of UTI among Pregnant Women \\
\hline
\end{tabular}

\begin{tabular}{|c|c|c|c|}
\hline $\begin{array}{c}\text { Age Groups } \\
\text { (Years) }\end{array}$ & $\begin{array}{c}\text { Number } \\
\text { Examined }\end{array}$ & $\begin{array}{c}\text { Number } \\
\text { Positive }\end{array}$ & $\begin{array}{c}\text { Positive } \\
\%\end{array}$ \\
\hline $16-20$ & 40 & 03 & $3.06 \%$ \\
\hline $21-25$ & 94 & 48 & $48.97 \%$ \\
\hline $26-30$ & 126 & 36 & $36.73 \%$ \\
\hline $31-35$ & 56 & 09 & $9.18 \%$ \\
\hline $36-40$ & 34 & 02 & $2.06 \%$ \\
\hline Total & $\mathbf{3 5 0}$ & $\mathbf{9 8}$ & $\mathbf{1 0 0 \%}$ \\
\hline \multicolumn{4}{|c|}{ Table 2. Prevalence of UTI in Pregnant Women } \\
in Relation to Age \\
\hline
\end{tabular}

\begin{tabular}{|c|c|c|c|}
\hline $\begin{array}{c}\text { Gestational } \\
\text { Age }\end{array}$ & $\begin{array}{c}\text { Number } \\
\text { Examined }\end{array}$ & $\begin{array}{c}\text { Number } \\
\text { Positive }\end{array}$ & $\begin{array}{c}\text { Positive } \\
\text { \% }\end{array}$ \\
\hline 1-12 weeks & 43 & 07 & $7.14 \%$ \\
\hline $13-25$ weeks & 71 & 19 & $19.38 \%$ \\
\hline $26-40$ weeks & 236 & 72 & $73.46 \%$ \\
\hline Total & $\mathbf{3 5 0}$ & $\mathbf{9 8}$ & $\mathbf{1 0 0 \%}$ \\
\hline \multicolumn{3}{|c|}{ Table 3. Prevalence of UTI in Pregnant Women in } \\
Relation to Gestational Age \\
\hline
\end{tabular}

\begin{tabular}{|c|c|c|c|}
\hline Gravidity & $\begin{array}{c}\text { Number } \\
\text { Examined }\end{array}$ & $\begin{array}{c}\text { Number } \\
\text { Positive }\end{array}$ & $\begin{array}{c}\text { Positive } \\
\text { \% }\end{array}$ \\
\hline Primi gravid & 36 & 9 & $9.18 \%$ \\
\hline Second gravid & 86 & 32 & $32.65 \%$ \\
\hline Multi gravid & 228 & 57 & $58.16 \%$ \\
\hline Total & $\mathbf{3 5 0}$ & $\mathbf{9 8}$ & $\mathbf{1 0 0 \%}$ \\
\hline \multicolumn{3}{|c|}{ Table 4. Prevalence of UTI in Pregnant Women in } \\
Relation to Gravid
\end{tabular}




\begin{tabular}{|c|c|c|}
\hline Pathogens & Number Isolated & Positive \% \\
\hline E. coli & 56 & $57.14 \%$ \\
\hline Enterococcus & 24 & $24.48 \%$ \\
\hline Klebsiella & 8 & $8.16 \%$ \\
\hline Pseudomonas & 6 & $6.12 \%$ \\
\hline Proteus & 4 & $4.08 \%$ \\
\hline Total & $\mathbf{9 8}$ & $\mathbf{1 0 0 \%}$ \\
\hline $\begin{array}{c}\text { Table 5. Percentage of Isolation of various Significant } \\
\text { Pathogens in Urine of Pregnant Women }\end{array}$ \\
\hline
\end{tabular}

\section{DISCUSSION}

Urinary tract infections are one of the common infections occurring during pregnancy. The intent of present study is to determine the prevalence of urinary tract infection in pregnancy. A total of 350 pregnant women were included in the study. In this study out of 350 pregnant cases, 98 patients showed significant bacterial growth making an overall prevalence of $28 \%$.

Maternal age was not found to be a significant risk factor in this study. In literature, only a significant increasing risk of $1 \%-2 \%$ is reported per decade of age, $(2,4)$ which does not become evident in this study. The highest incidence is $21-25$ years followed by 26 - 30 years and 31 - 35 years. The reason could be due to the fact that many women within this age group are likely to have had many children before the present pregnancy and it has been reported that multiparity is a risk factor for acquiring bacteriuria in pregnancy. ${ }^{(13,18)}$ Sexual activity and certain contraceptive methods are also said to increase the risk, ${ }^{(19)}$ and women are mostly sexually active at this age. The report of this study is also similar to that of Leigh(20) and Onuh et al,(21) who also found the similar age group has highest incidence in developing urinary tract infection in pregnancy.

Multiparity has an increased risk factor of developing bacteriuria among pregnant women. Leigh(20) and Sharma JB et al(22) had similar observation regarding the risk of urinary incontinence and other urinary problem, which according to them increases by $37.04 \%$ with parity of $>3$ as compared to $18.75 \%$ in nulliparous, but disagreement was evident with the findings of Onuh et al(21) who reported that there was no relationship to parity.

In this study ninety eight (98) urine samples gave significant growth amounting to $28 \%$ prevalence, which is nearly similar to Onuh and colleagues(21) who reported prevalence of $32.7 \%$. This study does not agree with that of Akinloye et al(23) who reported $21.7 \%$, a bit lower to the present study. Furthermore, the prevalence of this study does not agree with that of Onyemelukwe et al(24) who reported a prevalence of $12.7 \%$ and also with Leigh(20) and Brook et al(25) who reported a prevalence of $1 \%-10 \%$. This difference may be due to the inclusion of both symptomatic and asymptomatic pregnant woman in this study or as a result of different socioeconomic status of the pregnant women.

In this study, the frequency of urinary tract infection was higher in the third trimester compared to the first and second trimester. This is in agreement with Leigh,(20) who reported an increased frequency of urinary tract infection in third trimester compared to the first and second trimester of pregnancy. However, this report does not agree with Onuh et al,(21) who reported a higher prevalence of urinary tract infection in the second trimester compared to the third trimester. This difference may be as a result of either change in urinary stasis and vesicoureteral reflux or decrease in urinary progesterones and oestrogens in the various trimesters of pregnancy.

\section{CONCLUSION}

In this study, the prevalence rate of urinary tract infection during pregnancy is $28 \%$. The physiological changes of pregnancy predispose women to UTI, so does other factors such as age, sexual activity, multiparity, previous history of UTI and socio-economic conditions. All pregnant women should be screened for UTI with a urine culture, treated with antibiotics and if the culture is positive and then retested for cure. The goal of early diagnosis and treatment of UTI during pregnancy is to prevent complications with all the added benefits to the mother and foetus.

\section{REFERENCES}

[1] Theodore M. Prevalence and antibiogram of urinary tract infections among prison inmates in Nigeria. The Internet Journal of Microbiology 2007;3(2):12-23.

[2] Brook GF, Butel JS, Moses SA. Jawetz Melmick and Adelberg's medical microbiology. 22 ${ }^{\text {nd }}$ edn. New York: McGraw-Hill 2001:637-8.

[3] Bacak SJ, Callaghan WM, Dietz PM, et al. Pregnancyassociated hospitalizations in the United States, 19992000. American Journal of Obstetrics and Gynecology 2005;192(2):592-7.

[4] Delzell JE, Lefevre ML. Urinary tract infections during pregnancy. American Family Physician 2000;61(3):713-20.

[5] Orenstein R, Wong ES. Urinary tract infections in adults. American Family Physician 1999;59(5):122534.

[6] Franklin TL, Monif GR. Trichomonas vaginalis and bacterial vaginosis. Coexistence in vaginal wet mount preprations from pregnant women. J Repord Med 2000;45(2):131-4.

[7] Mittal P, Wing DA. Urinary tract infections in pregnancy. Clin Perinatol 2005;32(3):749-64.

[8] Schnarr J, Smaill F. Asymptomatic bacteriuria and symptomatic urinary tract infections in pregnancy. Eur J Clin Invest 2008;38 Suppl 2:50-7.

[9] Alemu A, Moges F, Shiferaw Y, et al. Bacterial profile and drug susceptibility pattern of urinary tract infection in pregnant women at University of Gondar teaching hospital, Northwest Ethiopia. BMC Res Notes 2012;5:197.

[10] Emamghorashi F, Mahmoodi N, Tagarod Z, et al. Meternal urinary tract infection as a risk factor for neonatal urinary tract infection. Iran J Kidney Dis 2012;6(3):178-80.

[11] Johnson EK, Kim ED, FACS. UTIs in pregnancy. Update: March 29, 2011.

[12] Masinde A, Gumodoka B, Kilonzo A, Mshana SE. Prevalence of urinary tract infection among pregnant women at Bugando Medical Centre, Mwanza, Tanzania. Tanzan J Health Res 2009;11(3):154-9.

[13] Patterson TF, Andriole VT. Bacteriuria in pregnancy. Infect Dis Clin North Am 1987;1(4):807-22.

[14] Scott JR, Whitehead ED, Naghes HM. Dan Forty obstetrics and gynaecology. $6^{\text {th }}$ edn. Boston: McGrawHill 1990;60-80. 
[15] Giraldo PC, Araujo ED, Junior JE, et al. The prevalence of urogenital infections in pregnant women experiencing preterm and full-term labor. Article ID 878241, Infect Dis Obstetrics Gynecol 2012;2012:1-4.

[16] Raza S, Pandey S, Bhatt CP. Microbiological analysis of isolates in Kathmandu Medical College Teaching Hospital, Kathmandu, Nepal, Kathmandu Univ Med J (KUMJ) 2011;9(36):295-7.

[17] Sujatha R, Nawani M. Prevalence of asymptomatic bacteriuria and its antibacterial susceptibility pattern among pregnant women attending the antenatal clinic at Kanpur, India. J Clin Diagn Res 2014;8(4):DC01DC03.

[18] Barr JG, Ritchie JW, Henry 0, et al. Microaerophilic/anaerobic bacteria as a cause of urinary tract infection in pregnancy. $\mathrm{Br} \mathrm{J}$ Obstet Gynaecol 1985;92(5):506-10.

[19] Bandyopadhyay S, Thakur JS, Ray P, et al. High prevalence of bacteriuria in pregnancy and its screening methods in North India. J Indian Med Assoc 2005;103(5):259-62, 266.
[20] Leigh D. Urinary tract infections. In: Parker MT, Darden BI. eds. Topple and Wilson's Principles of bacteriology, virology and immunity. Vol 3. Philadelphia: BC Decker 1989:197-211.

[21] Onuh So, Umeora OUJ, Igberase Go, et al. Microbiological isolates and sensitivity pattern of urinary tract infection in pregnancy in Benin city, Nigeria. Ebonyi Medical Journal 2006;5(2):48-52.

[22] Sharma JB, Aggarwal S, Singhal S, et al. Prevalence of urinary incontinence and other urological problems during pregnancy: a questionnaire based study. Arch Gynecol Obstet 2009;279(6):845-51.

[23] Akinloye 0, Ogbolu DO, Akinloye OM, et al. Asymptomatic bacteriuria of pregnancy in Ibadan, Nigeria: a re-assessment. $\mathrm{Br} \mathrm{J}$ Biomed Sci 2006;63(3):109-12.

[24] Onyemelukwe NF, Obi SN, Ozumba BC. Significant Bacteriuria in pregnancy in Enuhun, Nigeria. Journal of College of Medicine 2003;8(2):20-2. 